ISSN : $2460-7797$

e-ISSN : $2614-8234$

Website : jurnal.umj.ac.id/index.php/fbc

Email : fibonacci@umj.ac.id

\title{
ANALISIS HIGH ORDER THINKING SKILL (HOTS) SISWA DALAM MENYELESAIKAN SOAL OPEN ENDED MATEMATIKA
}

\author{
Maylita Hasyim $^{1)^{*}}$, Febrika Kusuma Andreina ${ }^{2)}$ \\ ${ }^{1,2)}$ Program Studi Pendidikan Matematika, STKIP PGRI Tulungagung \\ J1. Mayor Sujadi Timur No. 7 Plosokandang, Tulungagung, 66221 \\ *maylita@stkippgritulungagunga.ac.id
}

\begin{abstract}
Abstrak
Saat ini siswa dituntut untuk lebih kreatif dalam menyelesaikan masalah matematika yang mengarah pada berpikir High Order Thinking Skill (HOTS) yaitu siswa menerapkan pengetahuan dan keterampilan yang telah dikembangkan selama pembelajaran dalam konteks baru. Pemberian Open Ended Problems (OEP) atau problem terbuka artinya permasalahan dengan pemecahan berbagai cara (flexibility) dan solusinya juga bisa beragam (multi jawab, fluency) sehingga siswa diberi kesempatan untuk berpikir HOTS dalam menyelesaikan OEP. Penelitian ini bertujuan untuk menganalisis HOTS siswa dalam menyelesaikan soal OEP dalam pembelajaran matematika. Jenis penelitian ini yaitu kualitatif, dengan metode penyajian deskriptif dan pendekatan studi kasus. Subjek dalam penelitian ini yaitu enam orang siswa kelas X MIPA-5 SMA Negeri 2 Trenggalek tahun pelajaran 2017/2018 yang dipilih berdasarkan tingkat kemampuan menyelesaikan soal OEP. Teknik pengumpulan data yang digunakan dalam penelitian ini yaitu tes tertulis yang disajikan dalam OEP dan wawancara. Berdasarkan hasil penelitian dapat disimpulkan bahwa HOTS siswa ditentukan oleh kemampuan siswa dalam memecahkan OEP, semakin tinggi kemampuan siswa dalam memecahkan OEP maka semakin banyak indikator HOTS yang dicapai. HOTS siswa dengan kemampuan tinggi mampu memenuhi indikator menganalisis, mengevaluasi, hingga mencipta. HOTS siswa dengan kemampuan sedang maтри memenuhi indikator menganalisis dan mengevaluasi. HOTS siswa dengan kemampuan rendah mampu hanya memenuhi indikator menganalisis, dan belum dapat dikatakan memenuhi indikator mengevaluasi dan mencipta.
\end{abstract}

Kata Kunci: high order thinking skill (HOTS), kemampuan, matematika, open ended problem (OEP), Matematika

\section{PENDAHULUAN}

(Sanderson, 2003) mengemukakan matematika sebagai ilmu memiliki karakteristik-karakteristik

tertentu. Karakteristik umum matematika adalah (1) memiliki objek kajian yang abstrak, berupa 
fakta, operasi (atau relasi), konsep dan prinsip; (2) bertumpu pada kesepakatan atau konvensi, baik berupa simbol-simbol dan istilah maupun aturan-aturan dasar (aksioma); (3) berpola pikir deduktif; (4) konsisten dalam sistemnya; (5) memiliki simbol yang kosong dari arti; dan (6) memerhatikan semesta pembicaraan (Hendriana \& Soemarmo, 2014, hal. 13).

Dalam mata pelajaran matematika berpikir merupakan indikator utama. (Yuningsih \& Sumardi, 2013), mendefinisikan berpikir adalah daya jiwa yang dapat meletakkan hubungan antara pengetahuan kita. Berpikir itu merupakan proses yang "dialektis" artinya selama kita berpikir, pikiran kita dalam keadaan tanya jawab, untuk dapat meletakkan hubungan pengetahuan kita. Dalam berpikir kita memerlukan alat yaitu akal (rasi). Hasil berpikir itu dapat diwujudkan dengan Bahasa Intelegensi yaitu suatu kemampuan jiwa untuk dapat menyesuaikan diri dengan situasi baru secara cepat dan tepat. Tingkat berpikir siswa sebenarnya memiliki empat tingkatan yaitu recall (hafalan), basic (pemahaman), critic (kritis), serta creative (kreatif).

Open Ended Problems (OEP) atau pembelajaran dengan problem terbuka artinya pembelajaran yang menyajikan permasalahan dengan pemecahan berbagai cara (flexibility) dan solusinya juga bisa beragam (multi jawab, fluency). Pembelajaran ini melatih dan menumbuhkan orisinalitas ide, kreativitas, kognitif tinggi, kritis, komunikasi-interaksi, sharing, keterbukaan, dan sosialisasi. Siswa dituntut untuk berimprovisasi mengembangkan metode, cara, atau pendekatan yang bervariasi dalam memperoleh jawaban. Selanjutnya siswa juga diminta untuk menjelaskan proses mencapai jawaban tersebut. Dengan demikian, model pembelajaran ini lebih mementingkan proses dari pada produk yang akan membentuk pola pikir keterpaduan, keterbukaan, dan ragam berpikir (Shoimin, 2014, hal. 109).

Berdasarkan uraian di atas maka dapat ditarik kesimpulan bahwa permasalahan dalam penelitian ini yaitu "bagaimana $\mathrm{High}$ Order Thinking Skill (HOTS) siswa dalam menyelesaiakan soal Open Ended Problem (OEP) pokok bahasan Sistem Persamaan Linear Tiga Variabel pada siswa kelas $\mathrm{X}$ SMAN 2 Trenggalek tahun pelajaran 2017/2018". Penelitian ini bertujuan untuk menganalisis High Order Thinking Skill (HOTS) siswa dalam menyelesaikan soal Open Ended Problem (OEP) pokok bahasan Sistem Persamaan Linear Tiga Variabel pada siswa kelas X SMAN 2 Trenggalek.

High Order Thinking Skill (HOTS) sebagaimana dijelaskan oleh adalah keterampilan berpikir yang lebih dari pada sekedar menghafalkan fakta atau konsep. HOTS mengharuskan siswa melakukan sesuatu atas fakta-fakta tersebut. Siswa harus memahami, menganalisis satu sama lain, mengkategorikan, memanipulasi, menciptakan cara-cara baru secara kreatif, dan menerapkannya dalam mencari solusi terhadap persoalan-persoalan baru (Riadi, 2016). Berikut indikator yang digunakan untukmenganalisis High Order Thinking Skill (HOTS) siswa disajikan pada tabel 1.

Tabel 1. Deskripsi Kemampuan HOTS

\begin{tabular}{cl}
\hline Kategori & \multicolumn{1}{c}{ Deskripsi } \\
\hline & $\begin{array}{l}\text { Menspesifikasikan aspek- } \\
\text { aspek/elemen }\end{array}$ \\
Menganalisis & Kata kerja: \\
(Analyze) & $\begin{array}{l}\text { membandingkan, } \\
\text { memeriksa, mengkritisi, } \\
\text { menguji }\end{array}$
\end{tabular}

Mengevaluasi Mengambil keputusan 


\begin{tabular}{|c|c|}
\hline Kategori & Deskripsi \\
\hline \multirow[t]{3}{*}{ (Evaluate) } & sendiri \\
\hline & $\begin{array}{l}\text { Kata kerja: evaluasi, } \\
\text { menilai, menyanggah, } \\
\text { memutuskan, memilih, } \\
\text { mendukung }\end{array}$ \\
\hline & $\begin{array}{l}\text { Mengkreasi ide/gagasan } \\
\text { sendiri }\end{array}$ \\
\hline $\begin{array}{c}\text { Mencipta } \\
\text { (Create) }\end{array}$ & $\begin{array}{l}\text { Kata kerja: } \\
\text { mengkontruksi, desain, } \\
\text { kreasi, mengembangkan, } \\
\text { menulis, } \\
\text { memformulasikan }\end{array}$ \\
\hline
\end{tabular}

Sumber: Anderson \& Krathwohl (2001)

\section{METODE PENELITIAN}

\section{Jenis dan Pendekatan Penelitian}

Jenis penelitian ini yaitu kualitatif deskriptif dengan pendekatan studi kasus. Penelitian kualitatif memiliki beberapa karakteristik. Karakteristik tersebut yaitu: (1) dilakukan dalam kondisi yang alamiah, (2) penelitian kualitatif lebih bersifat deskriptif yaitu data yang terkumpul berbentuk kata-kata atau gambar, sehingga tidak menekankan pada angka, penelitian kualitatif lebih menekankan pada proses dari pada produk atau outcome (4) penelitian kualitatif melakukan analisis data secara induktif, (5) penelitian kualitatif lebih menekankan makna (Sugiyono, 2011, hal 21-22).

\section{Prosedur Penelitian}

Prosedur pelaksanaan dalam penelitian ini adalah sebagai berikut: 1) Tahap Persiapan, menyusun proposal penelitian serta mengurus administrasi serta perjanjian ke sekolah yang dijadikan lpkasi penelitian.

2) Tahap Pelaksanaan, pada tahap ini peneliti memberikan soal tes open ended kepada subjek penelitian yaitu seluruh siswa kelas $\mathrm{X}$ MIPA-5 SMAN 2 Trenggalek. Setelah melaksanakan itu peneliti mengkoreksi hasil pekerjaan seluruh siswa dengan menggunakan pedoman penilaian, setelah itu peneliti melaksanakan wawancara kepada 6 subjek yang telah diambil secara purposive sampling pada setiap tingkat kategori yang dicari menggunakan standar deviasi. 3) Tahap Analisis Data, dalam tahapan ini peneliti menganalisis data hasil test dan wawancara yang telah dilakukan, kemudian peneliti mengklasifikasikan data yang diperoleh berdasarkan indikator kemampuan HOTS. 4) Peneliti membuat dan menuyun laporan dengan data yang telah diperoleh dalam melaksanakan penelitian.

\section{Subjek, Waktu dan Lokasi Penelitian}

Pertama peneliti menentukan subjek penelitian kemudian memberikan soal tes open ended materi Sistem Persamaan Linear Tiga Variabel (SPLTV) kepada siswa kelas X MIPA5. Berdasarkan hasil tes peneliti memilih 6 siswa, dimana 6 siswa tersebut 2 dari kelompok tinggi 2 dari kelompok sedang dan 2 dari kelompok rendah. Kemudian siswa tersebut diwawancara terkait dengan jawaban yang sudah mereka tuliskan. Pengambilan subjek dalam penelitian ini menggunakan teknik purposive sampling.

\section{Instrumen Penelitian.}

Peneliti menggunakan lembar soal tes dan pedoman wawancara. Pemberian tes open ended bertujuan untuk mengukur tingkat kemampuan HOTS siswa sesuai dengan indikator kemampuan HOTS. Sedangkan Pedoman wawancara yaitu inti dari pertanyaan yang akan ditanyakan secara langsung kepada siswa yang terpilih sebagai sample. Setiap pertanyaan dalam 
wawancara bertujuan untuk mengetahui pemahaman siswa dalam mengerjakan soal tes, sehingga selanjutnya peneliti mengetahui tingkat kemampuan HOTS siswa.

\section{Teknik Pengumpulan Data}

Data dalam penelitian ini digunakan untuk mengetahui bagaimana tingkat High Order Thinking Skill Siswa ditinjau dari kemampuan siswa dalam menyelesaiakan OEP pokok bahasan Sistem Persamaan Linear Tiga Variabel dalam pembelajaran matematika kelas X SMAN 2 Trenggalek. Teknik pengumpulan data yang dilakukan dalam penelitian ini yaitu 1) Tes Open Ended Problem digunakan untuk mengetahui tingkat HOTS siswa. Tes ini berupa 3 soal uraian dengan alokasi waktu 60 menit. 2) Wawancara dilakukan setelah siswa (subjek) selesai mengerjakan 2 butir soal uraian open ended problem. Wawancara dilaksanakan sebagai tolok ukur seberapa paham siswa dalam menyelesaikan permasalahan yang disajikan dan jawaban serta cara yang dipilih.

\section{Teknik Analisis Data}

Untuk mengetahui pengelompokkan setiap kemampuan HOTS maka menggunakan nilai rata-rata dan standar deviasi.

Rumus rata-rata (mean)

$\bar{X}=\frac{\sum_{\bar{i}=1}^{\mathrm{n}} X \bar{i}}{n}$

Keterangan:

$\bar{X}=$ rata - rata

$\sum_{i=1}^{n} X i=j u m l a h$ seluruh nilai data

$n=$ jumlah seluruh frekuensi
Rumus Standar Deviasi

$s=\sqrt{\frac{\sum_{i=1}^{n}(X i-X)^{2}}{n-1}}$

$s=$ standar deviasi

$n=$ ukuran sampel

Atau bisa menggunakan excel untuk lebih mudah dalam menghitung dan mengelompokkan tingkat kemampuan HOTS.

\section{HASIL DAN PEMBAHASAN}

Subjek penelitian ini adalah siswa kelas $X$ MIPA5 SMA Negeri 2 Trenggalek. Langkah pertama adalah melakukan observasi kelas yang meliputi observasi aktivitas guru dan aktivitas siswa di Kelas X MIPA5 SMA Negeri 2 Trenggalek. Selanjunya adalah pemberian tes tertulis open ended yang terdiri dari 3 soal. Tes tertulis soal open ended. Pengambilan data untuk intrumen tes open ended diperuntukkan bagi seluruh siswa kelas $\mathrm{X}$ MIPA5 SMA Negeri 2 Trenggalek. Setelah itu peneliti melaksanakan wawancara dengan subjek penelitian. Data wawancara direkam dengan alat perekam suara yang kemudian dirubah dalam bentuk transkrip wawancara.

Peneliti menggunakan data yang diperoleh dari hasil tes tulis soal open ended. Data skor tes tulis open ended digunakan untuk mengukur tingkat kemampuan HOTS siswa kelas X MIPA5 SMA Negeri 2 Trenggalek. Berdasarkan hasil nilai tes tulis, dari 36 siswa kelas $\mathrm{X}$ MIPA5 SMA Negeri 2 Trenggalek hanya diambil 6 siswa sebagai subjek penelitian yang terdiri dari 2 siswa kemampuan tinggi, 2 siswa kemampuan sedang, dan 2 siswa kemampuan rendah.

Data dalam penelitian ini merupakan data hasil dari tes tulis open ended yang 
skornya digunakan untuk menentukan tingkat kemampuan menggunakan standar deviasi. Adapun rincian skor subjek terpilih adalah sebagai berikut:

Tabel 2. Kategori Tingkat Kemampuan HOTS

\begin{tabular}{ccc}
\hline No & Interval & Keterangan \\
\hline 1 & $\mathrm{~N}<$ Mean - SD & Rendah \\
\hline 2 & $\begin{array}{c}\text { Mean }- \text { SD } \leq \text { Mean }+ \\
\text { SD }\end{array}$ & Sedang \\
\hline 3 & $\mathrm{~N}>$ Mean + SD & Tinggi \\
\hline
\end{tabular}

Tabel 3. Nilai Subjek Penelitian

\begin{tabular}{cccc}
\hline No & Subjek & Nilai & Keterangan \\
\hline 1 & T1 & 100 & Tinggi \\
\hline 2 & T2 & 100 & Tinggi \\
\hline 3 & S1 & 70 & Sedang \\
\hline 4 & S2 & 80 & Sedang \\
\hline 5 & R1 & 42 & Rendah \\
\hline 6 & R2 & 36 & Rendah \\
\hline
\end{tabular}

\section{Pembahasan Tingkat Kemampuan Tinggi}

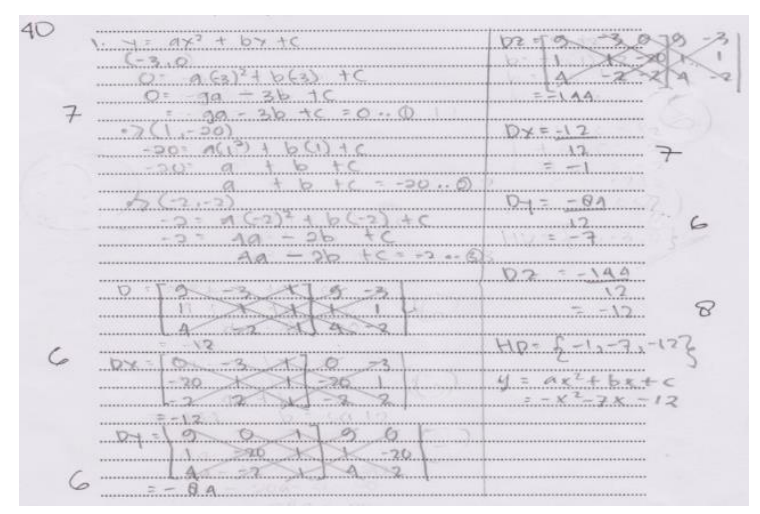

Gambar 1. Scan Jawaban Soal Nomor 1 Subjek T1

Dalam menyelesaikan soal nomor 1 , Subjek T1 memenuhi indikator "menganalisis", merujuk pada siswa dapat menentukan masing-masing persamaan dengan benar. Pada Gambar 1 siswa mampu mengganalisis dan menentukan masing-masing persamaan dengan benar. Indikator "mengevaluasi" merujuk pada siswa dapat memilih metode penyelesaian dengan tepat. Pada Gambar 1 siswa mampu memilih metode penyelesaian yang sesuai, siswa memilih menyelesaikan permasalahan yang ada menggunakan metode determinan matriks. Indikator "mencipta" merujuk pada siswa dapat menyimpulkan jawaban sesuai pertanyaan. Pada Gambar 1 siswa dapat menyimpulkan dari hasil jawaban sesuai pertanyaan dengan menuliskan hasil jawaban yang diperoleh.

Berdasarkan hasil wawancara dengan Subjek T1, bahwa pada indikator "menganalisis" Subjek T1 mengetahui titik koordinat dan persamaannya, pada indikator "mengevaluasi" Subjek T1 mengerjakan dengan metode determinan matriks, pada indikator "mencipta" Subjek T1 menuliskan jawaban yang diinginkan dari soal tersebut.

Berdasarkan hasil tes soal OEP dan wawancara maka dapat disimpulkan bahwa subjek berkemampuan tinggi T1 dan T2 menunjukkan bahwa dalam menyelesaikan soal Sistem Persamaan Linear Tiga Variabel (SPLTV) memiliki kemampuan berpikir yang tinggi pada kriteria kemampuan berpikir menganalisis, mengevaluasi, dan mencipta.

Subjek T1 dan T2 mampu menyebutkan poin utama sesuatu yang sedang dilakukan atau dihadapi. Terbukti bahwa mereka mampu menyebutkan informasi apa yang diketahui dan ditanyakan dalam soal. Mereka juga memberikan alasan-alasan yang mendukung kesimpulan yang diambil dengan tepat, yang kemudian digunakan pada saat proses penarikan kesimpulan. Subjek T1 dan T2 mampu mengungkapkan faktor-faktor penting yang perlu dipertimbangkan dalam membuat kesimpulan/keputusan. 
Pada saat menyelesaikan soal tersebut subjek T1 dan T2 dapat menyelesaikan masalah sesuai dengan langkah yang telah disusunnya, T1 dan T2 menuliskan kesimpulan dari jawabannya. Mereka juga memeriksa kembali langkah-langkah pengerjaannya apakah sudah benar langkah pengerjakannya. Mereka juga akan memperbaikinya jika terdapat kesalahan pada langkahnya. Mereka juga meyakini langkah-langkah dalam menyelesaikan masalah sudah benar. Dari beberapa penjelasan di atas, dapat disimpulkan bahwa T1 dan T2 memenuhi indikator menganalisis, mengevaluasi dan mencipta. Pada hasil wawancara menunjukkan bahwa subjek T1 dan T2 menjawab sesuai dengan apa yang dituliskan pada lembar kerja siswa, seperti menjelaskan tentang informasi yang di dapat dari soal-soal tersebut, menjelaskan metode yang digunakan dalam menyelesaikan soal tersebut, dan menjelaskan tentang penarikan kesimpulan pada setiap jawaban yang diperoleh.

\section{Pembahasan Tingkat Kemampuan Sedang}

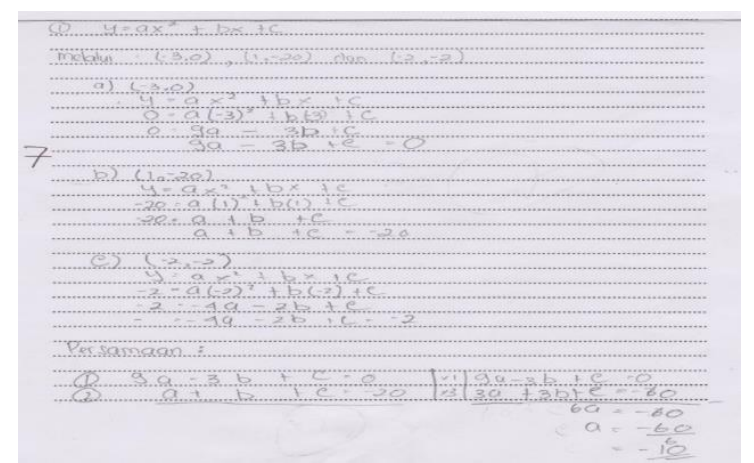

Gambar 2. Scan Jawaban Soal Nomor 1 Subjek S1

Dalam menyelesaikan soal nomor 1 , Subjek S1 memenuhi indikator "menganalisis", merujuk pada siswa dapat menentukan masing-masing persamaan dengan benar. Pada Gambar 2 Subjek S1 mampu mengganalisis dan menentukan masing-masing persamaan dengan benar. Indikator "mengevaluasi" merujuk pada Subjek S1 dapat memilih metode penyelesaian dengan tepat. Pada Gambar 2 siswa mampu memilih metode penyelesaian yang sesuai, siswa memilih menyelesaikan permasalahan yang ada menggunakan metode determinan matriks. Indikator "mencipta" merujuk pada siswa tidak dapat menyimpulkan jawaban sesuai pertanyaan. Pada Gambar 2 Subjek S1 tidak dapat menyimpulkan dari hasil jawaban sesuai pertanyaan dengan menuliskan hasil jawaban yang diperoleh.

Berdasarkan hasil wawancara dengan Subjek S1, bahwa pada indikator "menganalisis" Subjek S1 mengetahui titiktitik yang digunakan untuk mencari persamaannya, pada indikator "mengevaluasi" Subjek S1 hanya sampai menemukan persamaanya, pada indikator "mencipta" Subjek S1 belum mampu menuliskan jawaban yang diinginkan dari soal tersebut.

Berdasarkan hasil tes soal OEP dan wawancara maka dapat disimpulkan bahwa Subjek berkemampuan sedang yaitu S1 dan S2 menunjukkan bahwa dalam menyelesaikan soal Sistem Persamaan Linear Tiga Variabel (SPLTV) memiliki kemampuan berpikir yang sedang pada kriteria kemampuan berpikir menganalisis, mengevaluasi, dan mencipta.

Subjek S1 dan S2 mampu menyebutkan poin utama sesuatu yang sedang dilakukan atau dihadapi. Terbukti bahwa mereka mampu menyebutkan informasi apa yang diketahui dan ditanyakan dalam soal. Namun belum menuntaskan pekerjaannya. 
Pada saat menyelesaikan soal tersebut subjek S1 dan S2 dapat menyelesaikan masalah sesuai dengan langkah yang telah disusunnya, namun tidak semua soal mampu di selesaikan dengan benar, $\mathrm{S} 1$ dan S2 menuliskan kesimpulan dari jawabannya. Mereka sudah meyakini langkah-langkah dalam menyelesaikan masalah sudah benar namun kurangnya ketelitian. Berdasarkan beberapa penjelasan di atas, dapat disimpulkan bahwa S1 dan S2 memenuhi indikator menganalisis, dan mengevaluasi. Pada hasil wawancara menunjukkan bahwa subjek S1 dan S2 menjawab sesuai dengan apa yang dituliskan pada lembar kerja siswa, seperti menjelaskan tentang informasi yang di dapat dari soal-soal tersebut, menjelaskan metode yang digunakan dalam menyelesaikan soal tersebut, namun belum dapat menyelesaikan hingga penarikan kesimpulan.

\section{Pembahasan Tingkat Kemampuan Rendah}

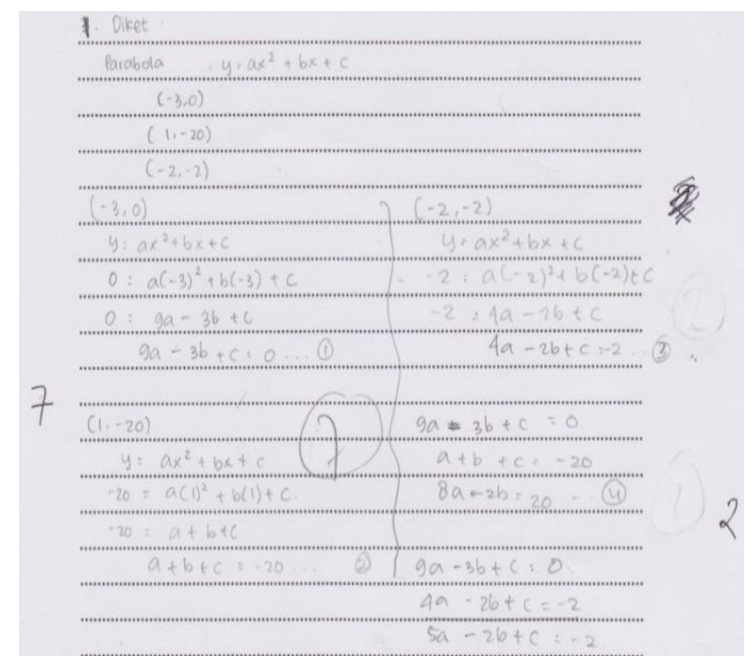

Gambar 3. Scan Jawaban Soal Nomor 1 Subjek R1

Dalam menyelesaikan soal nomor 1 , Subjek R1 memenuhi indikator "menganalisis", merujuk pada siswa dapat menentukan masing-masing persamaan dengan benar. Pada gambar 3 Subjek R1 mampu mengganalisis dan menentukan masing-masing persamaan dengan benar. Indikator "mengevaluasi" merujuk pada siswa dapat memilih metode penyelesaian dengan tepat. Pada Gambar 3 Subjek R1 belum mampu memilih metode penyelesaian yang sesuai, siswa memilih menyelesaikan permasalahan yang ada menggunakan metode determinan matriks. Indikator "mencipta" merujuk pada siswa tidak dapat menyimpulkan jawaban sesuai pertanyaan. Pada gambar 3 Subjek R1 tidak dapat menyimpulkan dari hasil jawaban sesuai pertanyaan dengan menuliskan hasil jawaban yang diperoleh.

Berdasarkan hasil wawancara dengan Subjek R1, bahwa pada indikator “menganalisis" Subjek R1 mengetahui titiktitik yang digunakan untuk mencari persamaannya, pada indikator "mengevaluasi" Subjek R1 belum menemukan persamaannya, pada indikator "mencipta" Subjek R1 belum mampu menuliskan jawaban yang diinginkan dari soal tersebut.

Berdasarkan hasil tes OEP dan wawancara maka dapat disimpulkan bahwa subjek berkemampuan rendah R1 dan R2 menunjukkan bahwa dalam menyelesaikan soal Sistem Persamaan Linear Tiga Variabel (SPLTV) memiliki kemampuan berpikir yang rendah pada kriteria kemampuan berpikir menganalisis, mengevaluasi saja.

Pada saat menyelesaikan soal tersebut subjek R1 dan R2 tidak dapat menyelesaikan masalah sesuai dengan langkah yang telah disusunnya. Mereka juga tidak memeriksa kembali langkahlangkah pengerjaannya apakah sudah benar langkah pengerjakannya. Mereka juga tidak meyakini langkah-langkah dalam 
menyelesaikan masalah sudah benar. Bahkan terdapat siswa kategori rendah yang tidak mengerjakan beberapa soal.

Dari beberapa penjelasan di atas, dapat disimpulkan bahwa R1 dan R2 memenuhi indikator menganalisis, belum memenuhi indikator mengevaluasi dan mencipta. Pada hasil wawancara menunjukkan bahwa subjek R1 dan R2 menjawab sesuai dengan apa yang dituliskan pada lembar kerja siswa, seperti menjelaskan tentang informasi yang di dapat dari soal-soal tersebut, menjelaskan kesulitan dalam memilih metode yang digunakan dalam menyelesaikan soal tersebut, sehingga terdapat kesalahan dalam menyelesaikan soal yang diberikan, bahkan belum dapat menuntaskan hingga akhir.

\section{SIMPULAN}

Berdasarkan hasil penelitian mengenai analisis high order thinking skill siswa dalam menyelesaikan soal open ended pokok bahasan Sistem Persamaan Linear Tiga Variabel pada siswa kelas X SMA Negeri 2 Trenggalek dapat disimpulkan bahwa: 1) HOTS siswa dengan kemampuan tinggi mampu memenuhi indikator menganalisis, mengevaluasi, hingga mencipta; 2) HOTS siswa dengan kemampuan sedang mampu memenuhi indikator menganalisis dan mengevaluasi; dan 3) HOTS siswa dengan kemampuan rendah mampu hanya memenuhi indikator menganalisis, dan belum dapat dikatakan memenuhi indikator mengevaluasi dan mencipta.

\section{DAFTAR PUSTAKA}

Budiman Agus, Jailani. 2014. "Pengembangan Instrumen Asesmen Higher Order Thinking Skill (HOTS) Pada Mata Pelajaran Matematika SMP Kelas VIII Semester I". Jurnal Riset Pendidikan Matematika. Vol. 1 (2), pp: 139-151.

Hendriana, H., \& Soemarmo, U. 2014. Penilaian Pembelajaran Matematika (Revisi). PT Refika Aditama.

J. Moleong, L. 2011. Metodologi Penelitian Kualitatif (Revisi). Bandung: PT Remaja Rosdakarya.

Kementerian Pendidikan dan Kebudayaan Direktorat Jenderal Pendidikan Dasar dan Menengah Direktorat Pembinaan Sekolah Menengah Atas. 2017. Higher-Order Thinking Skills (HOTS). [Online] Tersedia: http://slideplayer.info/slide/12409112. [25 Maret 2018].

Kurniati Dian, Harimukti Romi, dan Jamil Nur Aisyah. 2016. "Kemampuan Berpikir Tingkat Tinggi Siswa SMP di Kabupaten Jember Dalam Menyelesaikan Soal Berstandar PISA". Jurnal Penelitian dan Evaluasi Pendidikan. Vol. 20 (2), pp: 142-155.

Kuswana, W.S. 2013. Taksonomi Berpikir. Bandung: PT Remaja Rosdakarya.

Riadi, Arifin. 2016. "Problem Based Learning Meningkatkan Higher Order Thinking Skill Siswa kelas VIII SMPN 1 Daha Utara dan SMPN 2 Daha Utara". Math Didactic: Jurnal Pendidikan Matematika. Vol. 2 (3), pp: 154-163.

Shidiq Ari Syahidul, Masykuri Mohammad, Susanti Elvi. 2015. “Analisis Higher Order Thinking Skill (HOTS) Menggunakan Instrumen Two-Tier Multiple Choice Pada Materi Kelarutan dan Hasil Kali Kelarutan". Makalah Dalam: Seminar Nasional Pendidikan Sains, 19 November 2015. 
Maylita Hasyim dan Febrika Kusuma Andreina : Analisis High Order Thinking Skill (HOTS) Siswa dalam Menyelesaikan Soal Open Ended Matematika

FIBONACCI : Jurnal Pendidikan Matematika dan Matematika. Vol. 5 (1), pp: 55 - 64.

Suryapuspitarini Betha Kurnia, Wardono, Kartono. 2018. “Analisis Soal-Soal Matematika Tipe Higher Order Thinking Skill (HOTS) pada Kurikulum 2013 untuk mendukung Kemampuan Literasi Siswa". Makalah Dalam: Seminar Nasional Matematika, 20 Oktober 2018.

Yuningsih, Tri. 2013. Analisis High Order Thinking Skill Siswa Dalam Menyelesaikan Soal Open Ended Pokok Bahasan Integral Tak Tentu Fungsi Aljabar. Skripsi. Surakarta: Universitas Muhammadiyah Surakarta. 
FIBONACCI : Jurnal Pendidikan Matematika dan Matematika

Volume 5 No. 1 Bulan Juni Tahun 2019 